\title{
Substernal Goiter: a case to remember
}

1. Department of Internal Medicine. Centro Hospitalar Tondela-Viseu,E.P.E. Viseu, Portugal. 2. Department of Internal Medicine. Hospital Trofa Saúde Vila Real. Vila Real, Portugal.

http://dx.doi.org/10.1590/1806-9282.66.2.109

\section{SUMMARY}

Goiter is a localized or generalized thyroid hypertrophy. It can remain within the cervical region or grow down until it invades the mediastinum. The signs and symptoms depend on the size and location of the goiter. Although drugs and radioactive iodine are often used to treat thyroid disease, the presence of symptomatic substernal goiter is a clear indication for surgery. Death or postoperative complications rarely occur.

We present a case of a 71-year-old man with recurrent thyroid pathology in the form of substernal goiter and hyperthyroidism even after partial thyroidectomy. The importance of this relates to the clinical evolution, volume, and location of the goiter as well as the surgical and pharmacological approach.

KEYWORDS: Goiter. Goiter, substernal/surgery. Hyperthyroidism.

\section{INTRODUCTION}

A 71-year-old man, with istmo-lobectomy of the left thyroid, was referred with hypothyroidism. In 4 months, he recovered from a euthyroidism state under levothyroxine $50 \mathrm{\mu g}$. Cervical ultrasound showed a heterogeneous right lobe with two small hypoechoic nodules of $5 \mathrm{~mm}$. Two years later, in the Emergency Department, he presented persistent irritative cough and dysphonia with a month of evolution and without dysphagia, difficulty breathing, or fever. Upon examination, there were no palpable thyroid or cervical adenopathies, oropharynx without alterations, blood pressure of 142/70 $\mathrm{mmHg}$, heart rate of $99 \mathrm{bpm}$, temperature of $37^{\circ} \mathrm{C}$, eupneic on ambient air, rhythmic on cardiac auscultation, vesicular murmurs on pulmonary auscultation, and absence of peripheral edema. He started systemic corticosteroid therapy due to irritative cough and dysphonia. Blood tests showed hyperthyroidism [TSH $<0.01 \mathrm{mUI} / \mathrm{L}$ ( 0.350 $5.500 \mathrm{mUI} / \mathrm{L})$, Free T4 $2.2 \mathrm{ng} / \mathrm{dL}(0.9-1.8 \mathrm{ng} / \mathrm{dL})$, Free T3 $4.6 \mathrm{pg} / \mathrm{mL}(2.0-4.2 \mathrm{pg} / \mathrm{mL})]$ and calcitonin $<1.00$ $\mathrm{pg} / \mathrm{ml}(0.40-18.90 \mathrm{pg} / \mathrm{mL})$. The patient started propylthiouracil $100 \mathrm{mg}$ tid. A chest radiograph showed an enlargement of the mediastinum. Cervico-thoracic computed tomography revealed a solid mediastinal mass originated on the lower half of the right lobe and the isthmus of the thyroid, which was compressing the left brachiocephalic vein (Fig. 1 and Fig.2). Thyroid scintigraphy showed marked hypertrophy 
of the right lobe with an extensive hypoactive area in the lower half and an extensive area with a slight uptake of the prolonged radiopharmaceutical. Bronchofibroscopy showed an extrinsic compression of the trachea. The patient underwent thyroidectomy without complications. Histological analysis revealed a benign follicular nodule. After thyroidectomy, the patient remained in euthyroidism with levothyroxine $100 \mu \mathrm{g}$.

\section{DISCUSSION}

There is a strong correlation between incidences of substernal goiter and cervical goiter and endemic regions ${ }^{1,2}$. The incidence of substernal goiter is difficult to assess, but $2.6-21 \%$ of these patients undergo thyroidectomy ${ }^{3}$. This variation reflects the lack of a definitive definition of substernal goiter. About 85-95\% of substernal goiters are benign and represent up to $7 \%$ of mediastinal tumors ${ }^{3}$. Other mediastinum lesions, including thymomas, lymphomas, dermoid cysts, pleuropericardial cysts, and neurogenic tumors, must be considered in the differential diagnosis.

Although 5 to $50 \%$ of the patients are asymptomatic, symptoms such as dyspnea, stridor, and dysphagia are common and result from substernal goiter compression of the trachea and/or esophagus 4 . Superior vena cava syndrome and progressive hoarseness are less common symptoms.

Hyperthyroidism is often associated with substernal goiter. Although drugs and radioactive iodine are

FIGURE 1. SUBSTERNAL GOITER

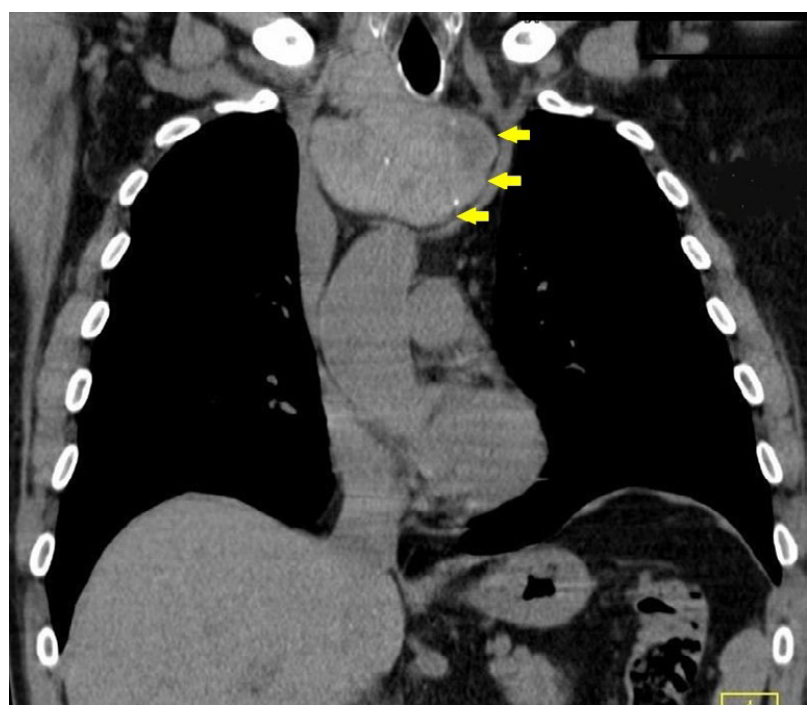

often used to treat thyroid disease, the existence of substernal goiter, particularly if symptomatic, is a clear indication for surgery ${ }^{3,5,6}$. In most cases, this type of goiters can be excised successfully through a transcervical approach, although transthoracic approaches are occasionally required ${ }^{7,8}$. Such as our clinical case, recurrence is not rare after partial thyroidectomy ${ }^{\mathbf{1 , 9}}$; therefore, some authors recommend systematic total thyroidectomy, even if the contralateral lobe appears healthy ${ }^{3,10}$.

Certain radiological findings may alert the surgeon to the possible need for such an approach. Computed tomography (CT) scanning is currently the most useful tool in the preoperative assessment of patients' anatomy. CT assesses the extension toward the aortic arch ${ }^{1,11}$, locates the goiter (anterior, posterior, or mixed) and any stenosis as well as pathological interaction with any other organs and the esophagus in particular ${ }^{1,12}$.

As highlighted in this case, patients undergoing thyroid surgery should have preoperative thyroid function studies as well as appropriate medical management of any thyrotoxicity to avoid thyroid storm ${ }^{10}$.

Postoperative mortality usually implicates cardio-respiratory failure ${ }^{13}$, or sometimes a hemorrhagic, infectious or thyrotoxic event, or even pulmonary embolism. The most frequent complications are

FIGURE 2. CERVICO-THORACIC COMPUTED TOMOGRAPHY WITH A SOLID MEDIASTINAL MASS ORIGINATED ON THE LOWER HALF OF THE RIGHT LOBE AND THE ISTHMUS OF THE THYROID

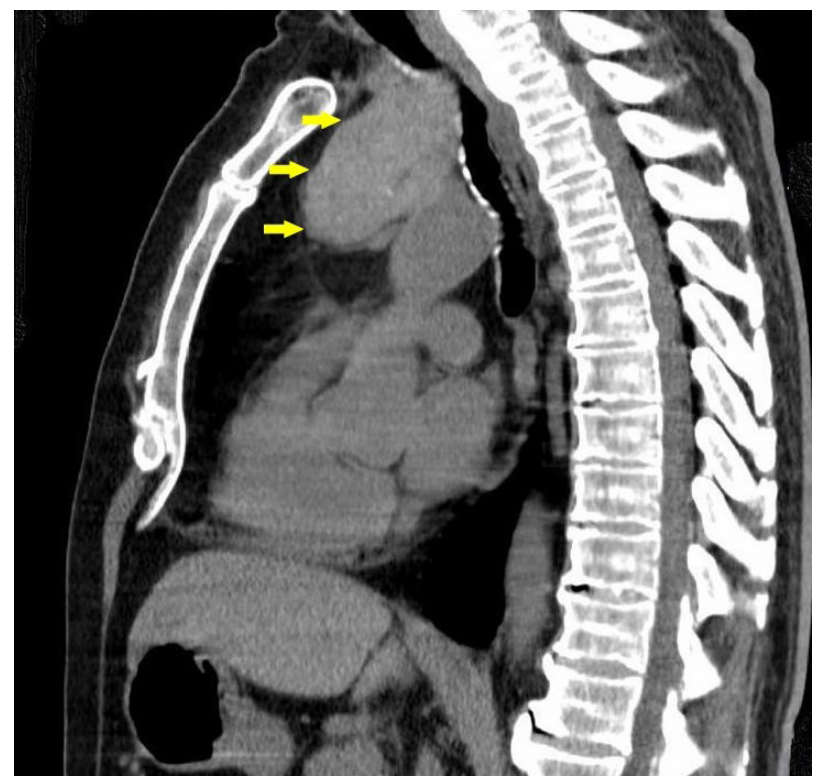


vascular and tracheoesophageal wounds. Recurrent nerve lesions are rarely recognized before extubation. Despite all of this, death or postoperative complications rarely occur ${ }^{6}$.

After surgery, supplementation with levothyroxine is required. The prognosis is generally good.

\section{Disclosure of interest}

The authors report no conflict of interest.

\section{Acknowledgments}

The authors wish to acknowledge Francisco Oliveira for helping with the English revision.

\section{Authors contributions}

Sara Simões Macedo collected data, performed the analysis, and wrote the paper; Mónica Teixeira performed the analysis and wrote the paper; Andreia Correia wrote the paper; Cátia Cabral wrote the paper.

\section{RESUMO}

O bócio é a hipertrofia da glândula tiroide localizada ou generalizada. Esta pode localizar-se na região cervical ou crescer através do mediastino. Os sinais e sintomas dependem do tamanho e da localização do bócio. Embora os fármacos e o iodo radioativo sejam frequentemente usados para tratar doenças tireoidianas, a presença do bócio subesternal sintomático é uma clara indicação para a cirurgia. A morte ou complicações pós-operatórias são raras.

Apresentamos o caso de um homem de 71 anos com recorrência de patologia tireoidiana sob a forma de bócio subesternal e hipertireoidismo após tireoidectomia parcial. A importância desse caso relaciona-se com a evolução clínica, o volume e a localização do bócio e a abordagem cirúrgica e farmacológica desse tipo de patologia.

PALAVRAS-CHAVE: Bócio. Bócio subesternal/cirurgia. Hipertireoidismo.

\section{REFERENCES}

1. Zainine R, El Aoud C, Bachraoui R, Beltaief N, Sahtout S, Besbes G. The plunging goiter: about 43 cases. Tunis Med. 2011;89(11):860-5.

2. Anders HJ. Compression syndromes caused by substernal goitres. Postgrad Med J. 1998;74(872):327-9.

3. Raffaelli M, De Crea C, Ronti S, Bellantone R, Lombardi CP. Substernal goiters: incidence, surgical approach, and complications in a tertiary care referral center. Head Neck. 2011;33(10):1420-5.

4. Cagli K, Ulas MM, Hizarci M, Sener E. Substernal goiter: an unusual cause of respiratory failure after coronary artery bypass grafting. Tex Heart Inst 1. 2005;32(2):224-7.

5. Wexler S, Yamane K, Fisher KW, Diehl JT, Hirose H. Single-stage operation for giant substernal goiter with severe coronary artery disease. Ann Thorac Cardiovasc Surg. 2011;17(5):524-7.

6. Daniel C, Andre N, Leroyer N. Goitre endothoracique. EMC Pneumol. 2000. [cited 2019 Aug 5]. Available from: https://www.em-consulte.com/ article/10886
7. Rolighed L, Rønning H, Christiansen P. Sternotomy for substernal goiter: retrospective study of 52 operations. Langenbecks Arch Surg. 2015;400(3):301-6.

8. Rodrigues MG, Araujo Filho VJF, Matos LL, Hojaij FC, Simões CA, Araujo Neto VJF, et al. Substernal goiter and laryngopharyngeal reflux. Arch Endocrinol Metab. 2017;61(4):348-53.

9. Benbakh M, Abou-elfadl M, Rouadi S, Abada RL, Roubal M, Mahtar M Substernal goiter: experience with 50 cases. Eur Ann Otorhinolaryngol Head Neck Dis. 2016;133(1):19-22.

10. Shaha AR. Surgery for benign thyroid disease causing tracheoesophageal compression. Otolaryngol Clin North Am. 1990;23(3):391-401.

11. Kabala JE. Computed tomography and magnetic resonance imaging in diseases of the thyroid and parathyroid. Eur J Radiol. 2008;66(3):480-92.

12. Burns P, Doody J, Timon C. Sternotomy for substernal goitre: an otolaryngologist's perspective. J Laryngol Otol. 2008;122(5):495-9.

13. Singh B, Lucente FE, Shaha AR. Substernal goiter: a clinical review. Am J Otolaryngol. 1994;15(6):409-16. 